\title{
WEB-BASED TOOLS AND INSTRUCTIONAL DELIVERY IN SELECTED SECONDARY SCHOOLS IN OWERRI EDUCATION ZONE 1, IMO STATE
}

\author{
Ajuzie Ndubuisi Ebeniza, Merry N. Ukegbu \\ School of Education, Alvan Ikoku Federal College of Education, Owerri. Imo State, Nigeria \\ E-mail address: ebenizaajuzie@yahoo.com
}

Keywords: ICT, Web-based tools, new technologies, social networking tools, and Instruction.

\begin{abstract}
The study was carried out to determine Web-based tools for instructional delivery in selected secondary schools in Owerri education zone 1 of Imo State. Three research questions were posed that guided the study. The study adopted expost facto design. The study comprised of 250 teachers selected from 65 secondary schools in Owerri education zone I, of Imo state. The researchers developed instrument named "Web-Based Tools for Instructional Delivery Questionnaire (WDTIDQ)" to gather information for the study. The result revealed that teacher's awareness on facebook and e-mail is high; also teacher's usage of facebook and e-mail in teaching and learning in the selected secondary school is high. Furthermore, there exist challenges to the use of web-based tools for instructional delivery in the selected secondary schools in Owerri educational zone 1 of Imo State, such as, lack of power supply, lack of awareness, lack of basic computing skills on the part of the teachers, lack of Internet connectivity in most of the secondary schools investigated and high cost of information and communication technology (ICT) facilities in these selected schools etc. Following from the findings of the study, it was recommended among others that Web-based tools should be provided for teachers use in teaching and learning process. Also, effective and accessible electricity services should be in place in schools for ICT to thrive. It is believed that if these measures are put in place teaching and learning in the secondary schools will be at a par with the developed countries of the world.
\end{abstract}

\section{INTRODUCTION}

Nigerian learners need to be taught systematically by teachers with emphasis on educationally programmed instruction and variety of content with special emphasis on computer and computer related technologies (Ajuzie, 2013). Instruction used in a generic sense, refers to any specifiable means of controlling or manipulating a sequence of events to produce the required modification of behavior through learning (Anyaogu, 2012). The new technologies have provided some of the solutions to the problems of teaching and learning (instruction) through the use of information and communication technologies or Web-based tools (Ifegbo, 2012). United nation educational scientific and cultural organization (2011) observed that educational systems around the world are under pressure to use the new information and communication technologies (ICTs) to teach the students the knowledge and skills needed in the 21st century. Contributing, Iwu (2005) and Ajuzie (2009) observe that ICTs improves sect instructions, provides concrete experience, reinforces verbal description, sustains greater retention and exposes students to more learning experiences. In concrete terms, web-based tools help instructional delivery in any educational process due to its dynamic, interactive, and engaging content, it has provided real opportunities for individualized instruction, enrich and deepen computing skills acquisition, motivate and engage learners in systematic learning process. Web-based tools which fall under Information and Communication Technologies (ICTs) has the potential to transform the way learning is delivered and promotes new opportunities thereby enhancing scholarship and enquires (Effiong \& Odey, 2014). ICTs can be defined as a diverse set of electronic technologies and technological tools and resources used to communicate, create, disseminate, store, and manage information (Tinio,2003; Adomi \& Kpangban, 2010). Kosoko-Oyedeko and Adedoja (2012) suggest that information and communication technologies have grown beyond our wildest imagination. Today, technology has introduced us to a faster and secure means of communication. Among these devices are laptop, apple iphone, androids, smart board, white board, digital cameras, smart phones, interactive white board, etc. 
Such new technologies and package with applications of social networking tools like twitter, Google, Facebook, Skype, You tube instant messages, quick office, Adope reader, e-mail, opera mini Uc browser, camcard etc makes teaching more interesting and learning easy. On the various forms of Web-based tools for instructional delivery, each of the technologies proves very effective in distinctive way (Rocha, 2011). Furthermore, the use of search engines such as Google, opera mini, UC browser etc enables both the teacher and the learner to access relevant information on every area of learning distance notwithstanding (Ajuzie, 2013, Paulus, 2007, Yusuf, 2010, and Zur, 2011) respectively. Using web-based tools in teaching and learning makes instructional delivery easy for teachers as it ignites possible content and easy ideas, a chance to share, read and post information for others and refer back to it at anytime, anywhere (Ibe-Bassey, 2011).

\section{THE PROBLEM}

Research has shown that the appropriate usage of ICTs-Web-based tools enable new ways of teaching and learning rather than simply allowing teachers to do what they have done before in a better way. However, observation from some of our secondary schools showed that teachers and learners still rely on text books and other materials physically media housed in libraries and are available in limited quantities for their educational needs. The researchers therefore deemed it fit to investigate into web-based tools and instructional delivery in selected secondary schools in Owerri education zone 1 , Imo State.

\section{PURPOSE OF THE STUDY}

The purpose of this study was to find out web-based tools and instructional delivery in selected secondary schools in Owerri education zone 1, Imo State. Specifically, the study sought to;

determine the level of awareness of web-based tools availability in secondary schools in Owerri education zone 1, for instructional delivery ascertain the extent of usage of web-based tools by teachers in the teaching of students in secondary schools in Owerri education zone 1, find out the challenges encountered by teachers in the usage of web-based tools in teaching and learning.

\section{RESEARCH QUESTIONS}

In order to effectively cover all the issues raised in the purpose of this study, the following research questions are posed;

- What is the level of awareness by teachers of web-based tools for instructional delivery in secondary schools in Owerri education zone 1, for instructional delivery?

- To what extent do teachers use web-based tools in secondary schools for instructional delivery in Owerri education zone 1,?

- What are the challenges encountered by teachers in the usage of web-based tools in instructional delivery in secondary schools in Owerri zone 1?

Method and Procedures: The research design adopted for this study is the expost facto design. This is based on the premise that the variables had already occurred and the researchers would not manipulate them, rather study them. The population of the study comprised of 250 teachers selected from 65 secondary schools in Owerri education zone I, of Imo state. The researchers developed instrument named "Web-Based Tools for Instructional Delivery Questionnaire (WDTIDQ)" to gather information for the study. The reliability index of the questionnaire was calculated using Cronbach alpha test and it gave 0.76 which was considered high enough for the study. The researchers made use of research assistant to administer the constructed questionnaire to the selected teachers in the zone and all administered questionnaires were returned too. Experts in Measurement and Evaluation Department, Imo State University Owerri validated the instrument. A four point rating scale of 1, 2, 3, and 4 standing for "Never", "Sometimes", "Often" and "Very often" were used for the study. Data were analyzed using percentage statistical tool. For this 
purposes of this study, the researchers considered all items with frequency of $50 \%$ and above as been available and utilized too while others less than $50 \%$ frequency are not.

\section{RESULTS}

Research Question 1: what is the level of awareness by teachers of web-based tools for instructional delivery in secondary schools in Owerri education zone 1, for instructional delivery?

Table 1: Showing frequency of responses of teachers awareness of Web-Based tools for instructional delivery

$\begin{array}{ccc}\text { Web-base tools } & \text { Frequency } & \text { Percentage of usage } \\ \text { Blog } & 24 & 9.6 \\ \text { Facebook } & 250 & 100 \\ \text { e-mail } & 220 & 88 \\ \text { RSSFEEDS } & 6 & 2.4 \\ \text { Wiki } & 15 & 6.0 \\ \text { Flicker } & 10 & 4.0 \\ \text { News group } & 7 & 2.8\end{array}$

Table 1 result revealed that only Web-based tools such as facebook and e-mail with percentage of 100 and 88 are available for instructional delivery in these schools while others are not. Therefore, teacher's awareness on facebook and e-mail is high.

Research Question 2: To what extent do teachers use web-based tools in secondary schools for instructional delivery in Owerri education zone 1?

Table 2: Showing frequency of responses of teachers on the usage of Web-Based tools for instructional delivery

$\begin{array}{ccc}\text { Web-base tools } & \text { Frequency } & \text { Percentage of usage } \\ \text { Blog } & 20 & 8.0 \\ \text { Facebook } & 198 & 79.2 \\ \text { e-mail } & 180 & 72.0 \\ \text { RSSFEEDS } & 9 & 3.6 \\ \text { Wiki } & 17 & 6.8 \\ \text { Flicker } & 11 & 4.4 \\ \text { News group } & 5 & 2.0\end{array}$

Table 2 showed that $79.2 \%$ of teachers have used facebook, with $72 \%$ of the teachers who have used e-mail. The RSFEEDS, Blog, Wiki, Flicker and News group percentage of usage is below 50\%. It means that teacher's usage of facebook and e-mail is high.

Research Question 3: what are the challenges encountered by teachers in the usage of webbased tools in instructional delivery in secondary schools in Owerri zone 1?

Table 3: Showing frequency of responses of teachers on the challenges to the use of Web-Based tools for instructional delivery

\begin{tabular}{lcc}
\multicolumn{1}{c}{ Challenges } & Frequency & Percentage \\
Lack of Awareness & 230 & $92.0 \%$ \\
Lack of Internet connectivity & 242 & $96.8 \%$ \\
Lack of computing skill & 210 & $84.0 \%$ \\
Lack of Power supply & 245 & $98.0 \%$ \\
High cost of ICT facilities & 173 & $69.2 \%$
\end{tabular}

Table 3 upheld that there exist challenges to the use of web-based tools for instructional delivery. All items have percentage frequency above 50\%. Hence, the listed challenges do exist and hinder teachers from applying web-based tools in teaching and learning process. 


\section{SUMMARY OF FINDINGS}

From the analysis above, it was observed that; teacher's awareness on facebook and e-mail is high. teacher's usage of facebook and e-mail is high.

there exist challenges to the use of web-based tools for instructional delivery. Such as, lack of power supply, lack of awareness, high cost of ICT facilities etc.

\section{DISCUSSION}

Teacher's awareness of web-based tools for instructional delivery It was observed from the analysis that teachers are aware of only facebook and e-mail. But they are not aware of other identified web-based tools like Blog, wiki, News group, RSS FEEDS etc. This is in line with Ezeoba (2007), who lamented that web-based tools awareness and availability is at the low ebb.

Teacher's use of web-based tools for instructional delivery

The study revealed that teachers only use facebook and e-mail in their teaching-learning situation. While other listed web-based tools were not used. This report is in line with the findings of Ajuzie (2009), Fakeye (2010), Ajuzie and Akukwe (2013), Akude, \& Ajuzie, (2011) which state that teachers can only utilize ICT tools that are readily available and accessible to them in teaching and learning process.

Challenges encountered by teachers in the usage of web-based tools in instructional delivery

The study showed that there exist challenges to the use of web-based tools for instructional delivery. Such as, lack of power supply, lack of awareness, high cost of ICT facilities etc. Contributing, Ajuzie, (2009), Afolabi, Adeyanju \& Adedapo (2010), Onwumere (2012) and Anyaogu (2012) opine that hinderances to ICT implementation are enormous, ranging from dearth of ICT facilities, to lack of trained personnel or lack of computing skills, lack of power supply etc.

\section{RECOMMENDATION}

In consideration of the findings of this research and their attendant implications, the researchers had to make the following recommendations:

Web-based tools should be provided for teachers use in teaching and learning process.

Effective and accessible electricity services should be in place in schools for ICT to thrive.

More computers should be supplied to secondary schools teachers at subsidized rates to enhance accessibility to teachers.

\section{CONCLUSION}

Usage of Web-based tools in all facets of education will go along way to enhancing instructional delivery and efficiency which will in turn produce teachers that will effectively contribute meaningfully to the growth and development of education. Especially now teaching has gone digital, Nigerian secondary school teachers should join the rest of the world in integrating ICT in teacher education to meet the demand of the 21 st century teaching and leaning. 


\section{References}

[1] Adomi, E.E. \& Kpangban (2010). Application of ICTs in Nigerian secondary schools. Library Philosophy \& Practice (e-journal), March, 1-8. http://digitalcommons.unl.edu/libphilprac/345.

[2] Afolabi, A. O., Adeyanju, O. L. \& Adedapo, Y. (2010). Media utilization for effective implementation of Universal Basic Education Programme in Nigeria. Journal of Educational Media \& Technology, Vol. 14 (1) pp 13-16.

[3] Ajuzie, N. E. (2009). Constraints to the implementation of ICT in senior secondary schools in Aba educational zone. An unpublished M.Ed Thesis, department of Curriculum Studies and Educational Technology, Imo State University.

[4] Ajuzie, N. E. (2013). Effects of hands-on training on education students' computing skills in State-owned universities in the South-East zone of Nigeria. An unpublished $\mathrm{PhD}$ Dissertation, department of Curriculum Studies and Educational Technology, Imo State University.

[5] Ajuzie, N. E. (2013). The Internet, an introduction in A. C. Akukwe (Ed.) Computer programs, theory \& practice. Owerri, Cherry Ben Ltd.

[6] Akude, I. \& Ajuzie, N. E. (2011). Undergraduate economics students' accessibility to and utilization of internet facilities in Alvan Ikoku Federal College of Education, Owerri. Journal of Educational Media \& Technology, Vol. 15, No. 1.

[7] Anyaogu, M. R. (2012). ICT instructional packages for tertiary institutions in Nigeria: The challenges and prospects, Journal of Educational Media \& Technology, Vol. 16 (1) pp. 1-5.

[8] Effiong, A. A. \& Odey, E. O. (2014). Utilization of Web-based tools and instructional delivery in secondary schools in Calabar education zone, Cross Rivers State. Journal of Educational Media \& Technology, Vol. 18, No. 1.

[9] Fakeye, D. O. (2010). Assessment of English Language teacher's knowledge and use of Information and communication technology in Ibadan Southwest L.GA of Oyo state. AmericanEurasian Journal of Scientific Research, 5(4) 56-59

[10] Ibe-Bassey, G.S. (2011). Human capacity building for information \& communication technology (ICT) integration in teacher education in Nigeria. A lead paper presented at the 32nd International Conference of the Nigeria Association for Educational Media \& Technology (NAEMT) Imo State University, Owerri, Unpublished.

[11] Ifegbo, P. C. (2012). Quality assurance. The Nigerian secondary school experience. Journal of educational media and technology. Vol. 16(1)

[12] Iwu, A.O. (2005). Information and communication technologogy as perceived by mathematics lecturers in Colleges of Education". An unpublished $\mathrm{PhD}$ dissertation, Imo State University, Owerri.

[13] Onwumere, A.O. (2012). Intergrating ICT in secondary education in Nigeria. Journal of Educational Media \& Technology, Vol. 12 (1) pp 85-90.

[14] Rocha, C. J. (2011). Essentials of social work policy practice in Cappella university, DSW 8002, Advanced knowledge of social work. Willy custom edition pp.51-88.

[15] Tinio, V. (2003) ICT in Education. Retrieved August 9, 2013 from http://www.apdip.net/publications/iespprimers/eprimer_edu.edu.pdf 
[16] United nation educational scientific and cultural organization (2011). Information and communication technology competency framework for teachers. Paris; Retieved June 10, 2015 from http://unesco.org/images/002134/2134755e.pdf

[17] Yusuf, M. (2010). Internet for research purposes. A lead paper presented at the 31st International Conference of the Nigeria Association for Educational Media \& Technology (NAEMT) held in Niger state College of Education, Minna from 20th - 26th September, 2010.

[18] Zur, O. (2011). To accept or not? How to trespond when clients send "friend request" to their psychotherapists or counselors on social networking sites. Retrieved from hhtp://www.zurinstitute.com/socialnetworking.html. 